\title{
Guidelines regarding thefts in libraries
}

Approved by ACRL and ALA, January 2003

by the Security Committee of ACRL's Rare Books and Manuscripts Section

\section{Section I. Preventing library theft}

A. Appoint a Iibrary Security Officer (ISO)

The LSO should be given authority by the library and the parent institution to act on their behalf while working with the institution's legal counsel and security force. Consult Section II of the ACRL "Guidelines for the Security of Rare Books, Manuscripts, and Other Special Collections" for a fuller description of the LSO's role, available from the ACRL office and published in CERL News (October, 1999); see also the RBMS Web site/Guidelines.

\section{B. Form a security planning group}

A security planning group, made up of the LSO and other appropriate personnel, will be responsible for developing a security plan to prevent theft and a detailed plan of action to follow when a theft is discovered. The plan may be a part of the institution's disaster plan or constitute a separate plan. The plans should not be public documents (e.g., they should not be posted on a Web site), but accessible only to appropriate library and institutional personnel.

\section{Communicate with the public relations department}

Establish a working relationship with the institution's public relations office so that timely and accurate announcements can be made to the press when a theft is discovered.

\section{Communicate with law enforcement agencies}

Establish contact and foster good working relations with law enforcement agencies - institutional, local, state, and/or federal - and determine which of them has original jurisdiction over the library (e.g., campus security, local or state police, etc.) and under which circumstances they should be called. The library should maintain a list of contacts in each level of law enforcement and discuss the plan of action with each. (See Appendix I for "Networking
Resources Directory for Protection and Recovery.") The FBI, as well as U.S. Customs or Interpol, might become involved if stolen items are suspected of being smuggled into or out of the country.

\section{E. Work for institutional and legislative} support

1. Work with the library's institutional administration to ensure their support for the prosecution of thieves. This support may range from the collection of evidence, which would be shared with prosecutors, to direct participation with the prosecution in preparation for and during the trial.

2. Work with appropriate institutional, local, and state groups to lobby for strengthening of state laws regarding library thefts and for diligent prosecution of such crimes. (See Appendix II for "Draft of Model Legislation: Theft and Mutilation of Library Materials.")

F. Report to library-and book and manuscript-related groups

1. Inform the local rare book, manuscript, and secondhand booksellers of the library's collecting areas and establish a procedure for quickly informing them of any theft that has occurred in your library. Thieves sometimes try to sell stolen property quickly, and sellers with knowledge of the library's collections can recognize, or at least be suspicious of, these genres of materials when they are offered.

2. Report the name of the ISO to the designated member of the RBMS Security Committee. Keep this person informed if successive ISOs are appointed.

3. Establish liaisons with appropriate Intemet electronic mailing lists and national stolen and missing book databases (see Appendix I for "Networking Resources Directory for Protection and Recovery") so that thefts can be reported immediately upon discovery. 


\section{About the guidelines}

The last revision of the ACRL "Guidelines Regarding Thefts in Libraries" was published in draft form in CERL News 55, 5 (1994) and approved in June of that year, just prior to the ALA Annual Conference. Just prior to the 1999 ALA Annual Conference, the ACRL Standards and Accreditation Committee and the RBMS Executive Committee asked the RBMS Security Committee to notify them whether the guidelines required revision.

After a review and discussion of the 1994 guidelines at the Security Committee's meeting at the 1999 Annual Conference, both the ACRL Standards and Accreditation Committee and the RBMS Executive Committee were notified that the guidelines would be revised. The guidelines were further discussed and revised by the Security Com-

\section{G. Know and implement preventive se- curity measures in the library}

1. Implement the ACRL "Guidelines for the Security of Rare Book, Manuscript, and Other Special Collections" (1999), available from the ACRL office and published in CERLNews (see RBMS Web site/ Guidelines).

2. Ensure that a unique ownership mark appears on all of the library's holdings; this will provide proof that materials, if stolen, belong to the library. RBMS strongly advocates the implementation of its marking guidelines for rare materials (see ACRL "Guidelines for the Security of Rare Book, Manuscript, and Other Special Collections," Appendix I.). RBMS also strongly advocates describing distinctive characteristics of individual copies in cataloging notes as another means of identifying appropriate items.

3. When providing complete catalog records at the point of receipt is not possible, some form of ownership record, however brief, is recommended. It should contain a brief author/title statement and a description of at least several copy-specific features (e.g., binding, marks of previous ownership, completeness, and bookseller and auction house descriptions). These records of purchase, gift, and provenance are especially important when materials are going to be added to a cataloging backlog.

4. Eliminate cataloging backlogs. Though difficult, this is an essential step in enhancing the security of a library's collections. Even if the backlog cannot be entirely eliminated, each library should reduce its backlog as much as it can. Stolen books that have been described in detail are far more easily identified and recovered than those that are not. Use mittee at the 2000 Midwinter Meeting and the 2000 Annual Conference. In January 2001, a draft version was mounted on the RBMS Web site and public comments sought. A public hearing was held on January 20,2002, at which additional changes were proposed. Some of the proposed changes were incorporated in the draft version subsequently published in CERL News in May 2002. At its June 17, 2002, meeting, the RBMS Security Committee approved the revised version as published in CERL News.

At the ALA Midwinter Meeting in Philadelphia (January 2003), the ACRL Standards and ACcreditation Committee, the ACRL Board, and the Al.A Standards and Review Commirtee formally approved the guidelines, and that version is published here.

the catalog record to describe copy-specific characteristics and bibliographic information that helps to distinguish among editions, issues, and states. Create machine-readable records for local public access and the national bibliographic databases. Participate in bibliographic projects that record detailed bibliographic descriptions.

5. Conduct regular inventories of both cataloged and uncataloged collections. This task is most effectively performed by staff members working in teams and should be conducted on a random basis. Proceeding through the collection in a predictable manner is not wise, since it may allow thieves to temporarily replace stolen materials. A simultaneous inventory of shelf list cards is also recommended, if this is not already a part of the procedure being followed. Inventories conducted even in small stages are valuable since they may reveal thefts (as well as misshelved books) and serve as a deterrent to any potential in-house thieves.

6. In special collections, record and verify (with photo ID) every user's name and address, and require them to complete a paper or electronic callslip and registration form, and to sign a reading room log. Whether housed in the collection or in the institutional archive, such documents should be kept permanently in order to be available to law enforcement authorities if thefts or vandalism later come to light. In order to safeguard reader confidentiality, access to filed or archived callslips should be restricted to the collection curator, division chief, and library director. Library policies and practices, especially in the course of investigating possible thefts, should not violate applicable federal, state, and local confidentiality laws. LSOs should be familiar with 
all applicable laws goveming personally identifiable information about library use

7. Follow the management practices recommended in the ACRL "Standards for Ethical Conduct for Rare Book, Manuscript, and Special Collections Librarians, with Guidelines for Institutional Practice in Support of the Standards," 2nd edition, 1994, available from the ACRL office, published in CERL News 54:4 (April 1993), and posted on the RBMS Web site.

8. Review materials in the library's general collections and open stacks for possible transfer to special collections or to a caged, limited access section of the library. Library staff should consult the ACRL "Guidelines on the Selection of General Collection Materials for Transfer to Special Collections," 2nd edition, available from the ACRL office and published in CERL News 54:11 (December 1993; revised on June 23,1999 , and posted on the RBMS Web site). Some libraries have identified rare materials in the open stacks in the course of special projects, such as reporting to the English Short Title Catalogue, or working through a collection development policy using the Research Libraries Group Conspectus.

9. A recent theft or act of vandalism may give an indication of a building area, subject, or artifactual genre that will be the target of future theft or mutilation. If it is appropriate, transfer to a more secure area materials related to those already stolen or mutilated. Remember that subject relationships may cross genre lines. The theft or mutilation of printed books or manuscripts may indicate that other genres of materials containing similar subject matter will become the targets of thieves and vandals.

10. Maintain a shelflist, preferably in paper form for special collections, in a secure area of the libraty. If the shelflist is electronic, it should be equipped with software that makes it secure from tampering and be duplicated in a backup tape stored off-site. Since the shelflist tells the librarian precisely where each book, pamphlet, tape, CD should be located, and because it contains copy-specific information about special collections materials, its maintenance and security are vital for detecting and recovering thefts.

11. Reader use of materials should be confined to a secure area monitored by staff trained in surveillance. Consult the ACRL "Guidelines for the Security of Rare Books, Manuscripts, and Other Special Collections," Section IV, for additional guidelines related to reading room security.

12. Install security cameras that cover special col lections reading rooms and any access points that security professionals deem appropriate. If security cameras use tapes, these should be retained for at least one month.
13. In conformity with applicable laws, formulate a policy regarding the physical detention of suspects.

\section{Section II. Reacting to library theft}

Every case of theft poses unique challenges, and many details of a library's response to a theft must be left to the judgement of its LSO and its Security Planning Group. However, these are the general guide lines that ACRL recommends.

\section{A. If you observe or have been alerted to a theft in progress \\ Immediate actions}

- Discreetly call for security personnel or the police (or signal a colleague to do so) and engage the suspect in non-threatening conversation in the hope that the suspect will remain in the reading room until help arrives.

- Do not confront a suspect with accusations. Behave with the suspect as you would with any patron, requesting that circulated materials be returned before the suspect leaves. If materials are missing, politely ask for them. The suspect may have made an honest mistake. If the suspect denies that s/ he ever had the materials or that they were returned, do not press the issue and do not put yourself at risk of physical harm. Follow your local policy regarding the physical detention of suspects.

- If the suspect is about to leave and help has not yet arrived, try to verify his/her registration information (e.g., contact a listed reference or call information to verify a residential address) before $\mathrm{s} / \mathrm{he}$ leaves.

- If a police officer finds reasonable cause that a theft has occurred, insist that the officer place the suspect under arrest. (Laws regarding grounds for arrest vary from state to state. Know the relevant laws of your state.) If there is evidence of theft, (e.g., library materials hidden on the suspect's person), do not agree to the suspect's release in return for the suspect's assurances that $s /$ he will return to face charges. If the officer will not make an arrest, attempt to persuade the officer to detain the suspect until the officer can verify his/her identity and place of residence.

- At the first opportunity, describe in writing the suspect's physical appearance and an account of the entire event as witnessed and /or related. This document should be presented to law enforcement authorities when they arrive. Do not in any way alter materials that might be considered evidence.

- Notify the ISO.

\section{B. If you discover a theft after it has oc- curred \\ Notification \\ Immediately notify the LSO who will:}


- Notify appropriate administrative officers.

- Notify and serve as liaison with institutional security personnel as well as local law enforcement personnel.

- Notify institutional public relations office.

\section{Gathering evidence}

The ISO will compile a list of missing items. (This does not mean that the entire library or collection needs to be inventoried.) However, after the immediate steps listed below have been taken, it is suggested that works similar to those that have been stolen be inventoried (See Section I.G.9). In consultation with the above groups of notified persons, gather all available evidence of theft. Such evidence should include:

- Detailed, copy-specific descriptions of missing materials.

- Chain of custody documentation for missing materials (including callslips or photocopies of them).

- Indications of unauthorized physical access to restricted areas.

- Report on any missing shelflist cards and call slips, and database tampering

- Report on any indication of systematic patterns of loss of materials.

\section{Action plan}

The LSO, in concert with appropriate library and institutional administration personnel, public relations personnel, security personnel, law enforcement (local, state, and federal, if necessary), and legal counsel will formulate a course of action that should include the following steps (in an order to be determined by those responsible for the process):

- Consultation and cooperation with judicial and law enforcement efforts on behalf of the library.

- Notification of appropriate stolen and missing books, databases, and other appropriate networks (see Appendix I for Networking Resources Directory for Protection and Recovery).

- Notification of local and regional booksellers and appropriate specialist sellers.

- Transfer of vulnerable items to a more secure location.

- Arrangement of appraisals upon discovery of missing items and, again, if they have been returned damaged.

- Questioning of staff regarding any suspicious behavior by users or other persons.

- Preparation of regular communications to staff about progress in the case, consistent with the investigation's integrity.

- Preparation of news releases.
- Preparation of responses by authorized library and institutional representatives to possible questions posed by the nerws media.

- Instructions to all library and institutional staff on how to respond to news media inquiries.

- Maintenance of internal record of actions taken during the case's progress, from its discovery to its final disposition.

\section{APPENDIX I \\ Networking resources directory for protec- tion and recovery}

Intemational.Association of Professional Security Consultants. hitp://www.iapsc.org; (949) 640-9918; Fax: (O49) 640-9911. Includes listing of professional security consultants with varying areas of expertise. Members of the organization cannot sell anything or represent any security firm.

"Library Security Resources: A Bibliography. "http:// www.libraryreference.org/security.html. Although somewhat dated, this bibliography includes dozens of articles from various sources related to library security.

ACRL/RBMS Security Committee c/o American Library Association, 50 E. Huron St. Chicago, IL 60611; phone: (800) 545-2433, ext. 2516; fax: (312) 440-9374; e-mail: ala@ala.org; homepage: http://www.ala.org.

RBMS homepage: http://www.tbnis.nd.edu. Both ALA and ACRL have several publications related to designing a library security program.

Society of AmericanArchivists. $527 \mathrm{~S}$. Wells, Chicago, IL 60607; phone: (312) 922-0140; fax: (312) 347-1452; email: sfox@archivists.org; homepage: http:// www.archivists.org. This organization has several books in print on special collections/archives security. It also has a security-related discussion list at saasecurity-1@comell.edu. This list is open only to SAA members, however.

Libnary Secunity Officers List. Susan Allen, moderator. Closed non-discussion electronic list for theft reporting and limited to library security officers only. For information contact the owner at e-mail: sallen@getty. edu

Exlibris electronic discussion list: Exlibris@ library.berkeley.edu. Electronic discussion list open to subscribers only, but subscription open to all. Has extensive web archives that include security topics available at http://palimpsest.stanford.edu. For further information, contact moderator Everett Wilkie at e-mail: ewilkie@ix.netcom.com. 
Arcbives E Archivisls Electronic Discussion list. Often includes discussions about library security. Archives are available at the host site. Address for posting is archives@listserv.muohio.edu. Subscription address is listserv@listserv.muohio.edu.

\section{APPENDIX II}

The draft of proposed legislation presented below may have to be modified in order to conform with federal and state laws regarding search and seizure. Also, the recourse to civil law that is available to a detained suspect may differ from state to state, and the draft legislation may have to be modified in order to meet such potential challenges. However, the wording definitions should be adhered to; they have been formulated with the assistance of legal counsel. Nationwide conformity to the definition of essential terminology in criminal legislation is desirable.

\section{Draft of model legislation: Theft and muti- lation of library materials}

\section{Declaration of purpose}

Because of the rising incidence of library theft and mutilation of library materials, libraries are suffering serious losses of books and other library property. In order to ensure that research materials are available for public use, it is the policy of this state to provide libraries and their employees and agents with legal protection to ensure security for their collections. It is the policy of this state to affirm that local, state, and federal prosecution of ctimes affecting books or other library property is executed with the same degree of diligence as is exercised in prosecution of crimes affecting other forms of property. Federal statute pertaining to stolen property is designed not only to implement federal-state cooperation in apprehending and punishing criminals who utilize, or cause to be utilized, channels of interstate commerce for transportation of property of which the owner has been wrongfully deprived, but also to deter original theft.

\section{Definition of terms}

"Library" means any public library; any library of an educational, benevolent, hereditary, historical, or eleemosynary institution, organization, or society; any museum; any repository of public or institutional records. "Book or other library property" means any book, plate, picture, photograph, print, painting, drawing, map, newspaper, magazine, pamphlet, broadside, manuscript, document, letter, public record, microform, sound recording, audiovisual material in any format, magnetic or other tape, catalog card or catalog record, electronic data processing record, artifact, or other documentary, written, or printed materials, or equipment, regardless of physical form or characteristics, belonging to, on loan to, or otherwise in the custody of a library.

\section{Proposed wording}

\section{Section I.a.}

Any person who willfully, maliciously, or wantonly writes upon, injures, defaces, tears, cuts, mutilates, or destroys any book, document, or other library property belonging to, on loan to, or otherwise in the custody of a library is guilty of a crime.

\section{Section I.b.}

The willful concealment of a book or other library property upon the person or among the belongings of the person or concealed upon the person or among the belongings of another while still on the premises of a library shall be considered prima facie evidence of intent to commit larceny thereof.

\section{Section I.c.}

The willful removal of a book or other library property in contravention of library regulations shall be considered prima facie evidence of intent to commit larceny thereof.

\section{Section I.d.}

The willful alteration or destruction of library ownership records, electronic or card catalog records retained apart from or applied directly to a book or other library property shall be considered prima facie evidence of intent to commit larceny of a book or other library property.

\section{Section II.a.}

An adult agent or employee of a library or that library's parent institution, whether or not that employee or agent is part of a security force, who has reasonable grounds to suspect that a person committed, was committing, or was attempting to commit the acts described in Section I may detain the suspect. Immediately upon detention, the library employee shall identify himself/herself and state the reason for his/her action. If, after the initial confrontation with the suspect, the adult agent or library employee has reasonable grounds to believe that at the time of detention that the person committed, was committing, or was attempting to commit the crimes set forth in Section I, said employee or agent may detain such a person for a time sufficient to summon a peace officer to the library. Said detention must be accomplished in a reasonable manner without unreasonable restraints or excessive force and may take place only on the premises of the library where the alleged crime occurred. Library premises include the interior of a building, structure, or other enclosure in which a library facility is located; the exterior appurtenances to such building structure, or other enclosure; and 
the land on which such building, structure, or other enclosure is located. Any person so detained by an employee or agent of a library shall promptly be asked to identify himself/herself by name and address. Once placed under detention, the suspect shall not be required to provide any other information nor shall any written and/or signed statement be elicited from the suspect until a police officer has taken the suspect into custody. The said employee or agent may, however, examine said property which the employee or agent has reasonable grounds to believe was unlawfully taken as set forth in Section I.b and/or I.c, or injured or destroyed as set forth in Section I.a and/or I.d. Should the detained suspect refuse to surrender the item for examination, a search may be made only of packages, shopping bags, handbags, or other property in the immediate possession of the person detained; no clothing worn by the suspect may be searched.

The activation of an electronic article surveillance device as a result of a person exiting the premises or an area within the premises of a library where an electronic article surveillance device is located shall constitute probable cause for the detention of such person by such library or agent or employee of the library, provided that such person is detained only in a reasonable manner and only for such time as is necessary for an inquiry into the circumstances surrounding the activation of the device, and provided that clear and visible notice is posted at each exit and location within the premises where such device is located indicating the presence of an anti-theft device. For purposes of this section, "electronic article surveillance device" means an electronic device designed and operated for the purpose of detecting the removal from the premises or a protected area within such premises, of any specially marked or tagged book or other library property.

\section{Section II.b.}

For the purposes of Section II.a, "reasonable grounds" shall include, but not be limited to, knowledge that a person has concealed or injured a book or other library property while on the premises of the library or the inability of the suspect to produce the library material for which there is a document proving that person had used but had not returned said material.

\section{Section II.c.}

In detaining a person who the employee or agent of the library has reasonable grounds to believe has committed, was committing, or was attempting to commit any of the crimes set forth in Section I, the said employee or agent may use a reasonable amount of non-deadly force when and only when such force is necessary to protect the employee or agent or to prevent the escape of the person being detained or the loss of the library's property.

\section{Section III.}

An adult agent or employee of a library who stops, detains, and/or causes the arrest of any person pursuant to Section II shall not be held civilly liable for false arrest, false imprisonment, unlawful detention, assault, battery, defamation of character, malicious prosecution, or invasion of civil rights of the person stopped, detained, and/or arrested, provided that in stopping, detaining, or causing the arrest of the person, the adult agent or employee had at the time of the stopping, detention, or arrest reasonable grounds to believe that the person had committed, was committing, or was attempting to commit any of the crimes set forth in Section I.

\section{Section IV.}

The fair market value of property affected by crimes set forth in Section I determines the class of offense: value under $\$ 500$ constitutes a misdemeanor; $\$ 500-\$ 5,000$ a Class I felony; above $\$ 5,000$, a Class II felony.

The aggregate value of all property referred to in a single indictment shall constitute the value thereof.

\section{Section V.}

A copy or abstract of this act shall be posted and prominently displayed in all libraries.

\section{Section VI.}

This act shall take effect upon passage.

\section{APPENDIX III \\ Related publications}

Association of College and Research Libraries. "Guidelines for the Security of Rare Book, Manuscript, and other Special Collections." In CERLNews (October, 1999, and posted on the RBMS Web site).

Association of College and Research Libraries. "Guidelines on the Selection of General Collection Materials for Transfer to Special Collections." In CERL News 54: 11 (December 1993; revised on 23 June 1999, and posted on the RBMS Web site)

Association of College and Research Libraries. "Standards for Ethical Conduct of Rare Book, Manuscript, and Special Collections Libraries and Librarians, with Guidelines for Institutional Practice in Support of the Standards." In CERL News 54:4 (April 1993), and posted on the RBMS Web site.

Society of American Archivists. Libraries and Archives: An Oveniew of Riskand Lass Pretention (1994). Society of American Archivists. Protecting Your Collections: AManual of Archizal Security (1995). 


\section{If patrons}

can't find the books you buy, you're throwing away your collection development dollars.

MARCIVE helps you maximize your development budget by dramatically increasing patron access to your collection, so the time and money you've spent won't go to waste.

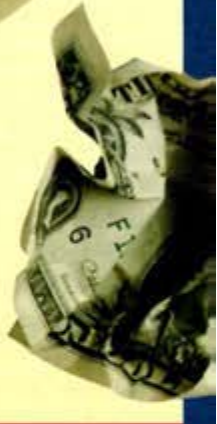

Authority Control

Obsolete, inconsistent access points prevent patrons from finding what you have. Bring your cataloging up to current standards - and then keep it up-to-date with Overnight Authorities.

\section{Conversion}

If you still have pockets of materials not in MARC format, let us convert them, so your patrons will know they exist. We can work from shelflist cards or computer records and integrate them into your catalog.

\section{MARC Record Enrichment}

For only $50 \mathrm{c}$ per hit, we can add Table of Contents (TOC) data to your records. Overnight, you will provide access to very specific or new topics even before LC creates a subject heading.

We add genre, characters, and more to your fiction cataloging, characteristics of biographees to your biography records, and summaries to both. Helps reader's advisory! 